\title{
Sustainable Development, Sustainability Leadership and Firm Valuation: Differences across EUROPE
}

\author{
Maria del Mar Miralles-Quiros, ${ }^{1 *}$ Jose Luis Miralles-Quiros ${ }^{1}$ and Irene Cuia Arraiano ${ }^{2}$ \\ ${ }^{1}$ Financial Economics, Faculty of Economics, University of Extremadura, Badajoz, Badajoz Spain \\ ${ }^{2}$ Lisbon Polytechnic Institute, Lisbon, Portugal
}

\begin{abstract}
Sustainable development is nowadays a high priority for firms all over the world. Consequently, numerous firms have increased their social responsibility initiatives, reinforcing the credibility and trust of their stakeholders. However, prior research about the relevance of sustainability leadership for the European investment community is scarce. In this context, the aim of this study is to examine whether sustainability leadership - proxied by membership of the Dow Jones Sustainability Index Europe - is value relevant for investors on the 10 major European stock markets over the 2001-2013 period. Our overall results reveal that there exist significant differences across markets. These findings are relevant especially for investors, but also for the managers of listed firms, market regulators and policymakers. Copyright @ 2017 John Wiley \& Sons, Ltd and ERP Environment
\end{abstract}

Received 9 December 2016; revised 27 February 2017; accepted 8 March 2017

Keywords: sustainable development; firm valuation; sustainability indices; stakeholder engagement; financial crisis

\section{Introduction}

USTAINABLE DEVELOPMENT IS NOWADAYS A HICH PRIORITY FOR COMPANIES. AS A CONSEQUENCE, FIRMS AROUND THE WORLD HAVE recently strived to adopt socially responsible practices and have committed to a management style that integrates economic, social and environmental principles (Kolk, 2008; Fifka, 2013; Pérez-López et al., 2015; Lee et al., 20I6; De Silva Lokuwaduge and Heenetigala, 20I7).

Thus, corporate social responsibility (CSR) has become an important strategy tool for managers because it results in sustainable competitive advantage (McWilliams et al., 20I6). CSR also reinforces the credibility and trust of stakeholders, who continually require firms to take responsibility for the impact of their activities on the environment and society (Pérez-López et al., 2015; Goettsche et al., 2016).

Shareholders are one of the primary stakeholder groups of a firm with employees and customers. An increasing number of them take social and environmental considerations into account in their investment decisions. This has meant that listed firms are more interested in adopting CSR practices in order to enhance their ability to access finance in the capital markets (Charlo et al., 2015). 
As evidence of the rise of socially responsible investment around the world, we can highlight the emergence of numerous sustainability indices. The Domini 400 social index was launched in I990, while the first indices of the Dow Jones Sustainability Index (DJSI) family were launched in I999 and some years later those of the FTSE4Good, Ethibel, KLD Analytics and Vigeo. These indices have been created to give investors a deeper insight into corporate sustainability performance and are therefore a key benchmark for both investors and firms (Searcy and Elkhawas, 20I2).

Firms are interested in belonging to sustainability indices because they are a powerful communication tool. First, it means the endorsement of their social responsibility practices by external institutions highly respected in the financial world. Second, as these indices use a best-in-class approach to the selection of firms, the firms included in the indices earn the reputation of being leaders in strategic areas that encompass economic, social and environmental dimensions (Lo and Sheu, 2007).

However, from an investor point of view, the potential benefit of investing in a firm listed on a sustainability index depends on how that information affects the market value of the firm (Robinson et al., 20II). In this context, we highlight two alternative theories as possible explanations for the impact of this kind of information on stock markets: the value-creating theory and the value-destroying theory.

The value-creating theory predicts that the inclusion of social and environmental responsibility in corporate strategies and practices reduces the risk for the firm and promotes the creation of long-term value. Thus, firms that are sustainability leaders can benefit in a number of ways, such as improving brand reputation (Maignan, 200I), improving employee productivity, increasing operational efficiency and improving relationships with the regulators, society and other stakeholders (Godfrey et al., 2009). In general, the sustainability commitment helps firms to maintain their market positions long term and opens the door to better investment projects (Yu and Zhao, 20I5). On the basis of this theory it is therefore expected that firms included in a sustainability index will have a higher market valuation than non-eligible firms.

In contrast, the value-destroying theory predicts that moving from the pursuit of profit to social responsibility can jeopardize opportunities to maximize profit for shareholders because the commitment to sustainability can lead to over-investment and other activities that are not in the best interests of the shareholders. This theory suggests that managers may engage in socially responsible activities to assist other stakeholders at the expense of the shareholders. The implementation of sustainability initiatives may not be profitable, and therefore is likely to destroy the value of the firm (Barnea and Rubin, 20IO; Yu and Zhao, 20I5).

However, research to date provides limited evidence that shareholders perceive sustainability leadership as important. Based on the Ohlson (I995, 200I) valuation model, Lourenço et al. (20I2) analyse the impact on the stock prices of North American and Canadian firms included in the DJSI North America index, while Lourenço et al. (20I4) present additional evidence for a sample of North American firms included in the DJSI US index. Subsequently, Kaspereit and Lopatta (20I6) present evidence of the impact on stock prices of firms that are included in the DJSI Europe index. However, this research only presents evidence for the European context as a whole. Thus, these overall findings are not suitable for generalization.

We agree with Ball et al. (2006), Cormier and Magnan (2007), Jackson and Apostolakou (2010) and Miras-Rodríguez et al. (2015) in arguing that national institutional contexts should be taken into account when evaluating the value relevance of sustainability measures. More precisely, we consider that the characteristics of each European market and the singularities of the legal system, as well as the social and environmental policies adopted by each government, can influence the market value of leading sustainability firms.

We therefore consider it is essential to expand the literature on sustainability leadership with additional research that provides evidence for different markets as well as for different economic stages. In this context, the aim of our research is to analyse whether sustainability leadership is valued in the markets of Denmark, Finland, France, Germany, Italy, the Netherlands, Norway, Spain, Sweden and the UK during the period 200I-20I3, taking into account the singularities of each market as well as the effect of the global financial crisis.

Our overall results reveal that European investors as a whole value this type of information positively and significantly, especially in the later years of the sample, providing support for the value-creating theory. However, when we conduct the analysis on each individual market we observe that the positive impact of sustainability leadership on firm value is primarily driven by firms quoted on the German and Swedish stock markets, while 


\section{Sustainability Leadership and Firm Valuation}

the results for markets with stronger shareholder protection and higher requirements for CSR transparency, such as the UK, are non-significant.

These findings about cross-country variation in valuation implications of sustainability leadership in a European context is of practical interest to investors and analysts when they make their investment decisions or prepare their investment advice, to managers in order to justify the CSR strategies implemented in the firms they manage, to policymakers in the implementation of new sustainability regulations and to other stakeholders, such as customers or clients interested in leader firms in terms of social and environmental issues.

The remainder of the paper is organized as follows. In the following section we present the existing literature in this field. In the next section we present the methodology used for our empirical research. The fourth section defines the database employed related to sustainability leadership and the European stock markets. The fifth section shows the results obtained and the last section sets out the conclusions of our study.

\section{Literature Review}

Investor awareness about sustainability as a viable corporate strategy has grown over the years. For this reason, there are an increasing number of studies that analyse the impact of corporate sustainability on stock markets. In this context, some authors such as Cheung (20II), Oberndorfer et al. (2OI3), Eisenbach et al. (20I4), Xu et al. (20I6) and Yadav et al. (2016), applying an event study methodology, document that investors perceive announcements relating to sustainability as positive news that allows them to obtain positive and significant standardized cumulative abnormal returns.

In another strand of literature, in which the objective is to analyse the long-term impact of sustainability, are those works that employ the Ohlson (I995, 200I) valuation model. These studies consider that accounting information is not sufficient to explain the market value of equity and, therefore, other information must be taken into account. As a result, numerous studies analyse the value relevance of environmental reports (Hassel et al., 2005; Cormier and Magnan, 2007; Moneva and Cuellar, 2009), social reports (Schadewitz and Niskala, 20Io; Berthelot et al., 2012; Cardamone et al., 20I2; Carnevale et al. 20I2; Carnevale and Mazzuca, 20I4; De Klerk et al., 20I5; Bowerman and Sharman, 20I6; Miralles-Quiros et al., 20I7) or environmental and social performance (Hussainey and Salama, 20I0; Al-Najjar and Anfimiadou, 20I2; Chapple et al., 20I3; Mervelskemper and Streit, 20I7).

As Bowerman and Sharman (2016) indicate, if investors combine the disclosure of sustainability with the financial information they use in their investment decisionmaking processes, then these two types of information together should better explain market valuations. However, existing research examining the joint valuation of financial and sustainability information offers inconclusive results, suggesting the need for future research.

There are several factors that could explain the mixed results found in the existing empirical evidence: the use of data from different countries and time periods, which makes it very difficult to compare studies, and even the use of different corporate sustainability measures. This is due to the fact that sustainability is not a variable and therefore cannot be measured (Marom, 2006). Moreover, the use of information produced by firms may lead to a selfreporting bias (Scholtens, 2009).

We therefore consider that it is more appropriate to employ sustainability information prepared by external firms or social rating agencies such as Sustainable Asset Management (SAM), which is responsible for developing the ranking of sustainable firms for the indices in the Dow Jones family. However, to our knowledge, the SAM sustainability ranking has been exclusively employed in the context of the Ohlson (I995, 200I) valuation model by Lourenço et al. (20I2, 20I4) and Kaspereit and Lopatta (20I6), the first two studies being based on the North American markets and the third one on European markets as a whole.

Specifically, Lourenço et al. (2OI2) find that membership of the DJSI North America index has a positive effect on the prices of firms listed on the Canadian and US stock markets during the 2007-2010 period, although they also document that these two markets penalize large profitable firms with a poor corporate sustainability performance. Later, Lourenço et al. (20I4) provide evidence of the direct and indirect effects on the stock market valuation of being included in the DJSI US index in the period 2008-20I0. However, they conclude that their findings, obtained in the 
US institutional framework, cannot be generalized to other countries with very different features, such as Germany and France.

More recently, Kaspereit and Lopatta (20I6) analyse whether relative corporate sustainability as measured by the SAM ranking and sustainability reporting in terms of Global Reporting Initiative (GRI) application levels are associated with a higher market valuation for a sample comprised by the 600 largest European companies over the 200I-20II period. Their results show that membership of DJSI Europe is associated with a higher market valuation. Meanwhile, the empirical evidence is less conclusive when GRI sustainability reporting is analysed. However, they do not provide a cross-country comparison and do not take into account the specific characteristics of each European stock market. Therefore, we consider that there is still a great deal of scope for research in this area since, as Cormier and Magnan (2007) suggest, the national institutional contexts should be taken into account when assessing the relevance of the market value of financial and non-financial performance measures.

\section{Methodology}

The difference between the market value of equity and its book value has led many researchers to explore the value relevance of non-financial information, generally concluding that accounting information has only a limited ability to explain the market value of equity.

In this context, Ohlson (I995, 200I) proposed a model based on the premise that the market value of equity is a function of the book value and accounting earnings (i.e. financial accounting information), as well as other nonfinancial information that may be considered relevant. However, he did not specify what the content of this additional information should be.

In this study, we consider inclusion in the DJSI Europe index as an indicator of sustainability leadership, since we believe that the firms included in this index gain the reputation of being leaders in strategic areas that encompass economic, environmental and social dimensions (Lo and Sheu, 2007; Lourenço et al., 20I4). Therefore, the proposed model is that expressed in the following equation:

$$
\mathrm{MV}_{i, t}=\alpha_{\circ}+\alpha_{\mathrm{I}} \mathrm{BV}_{i, t}+\alpha_{2} E_{i, t}+\alpha_{3} \mathrm{DJSIE}_{i, t}+\varepsilon_{i, t}
$$

where $\mathrm{MV}_{i, t}$ is the market value of firm $i$ in year $t, \mathrm{BV}_{i, t}$ is the book value of firm $i$ in year $t, E_{i, t}$ represents the earnings of firm $i$ for year $t$, DJSIE $_{i, t}$ is a dummy value that takes the value $\mathrm{I}$ if the firm $i$ is included in the DJSI Europe index in year $t$ or $\circ$ otherwise, and finally $\varepsilon_{i, t}$ is the error of firm $i$ in year $t$. The model's goodness of fit is provided by the $F$ statistic, which analyses the joint significance of the explanatory variables, as well as the adjusted $R^{2}$, which shows the proportion of the variability of the dependent variable explained by the explanatory variables.

On the basis of the Ohlson (I995, 200I) model, we expect the coefficients for the accounting variables to be significant and positive, indicating that accounting information is positively associated with the market value of equity and, therefore, it is relevant information for investors. Regarding the sign of the coefficient for the DJSI Europe variable, as we have indicated in the introduction, there are two alternative theories that could explain either a positive or a negative relationship with the market value of the leading sustainability firm: the value-creating and the value-destroying theories.

We must highlight that we employ a panel data methodology for our empirical research that consists of a combination of time series and cross-sectional data in a joint test and allows us to control individual unobservable heterogeneity - firm effect - as well as the endogenous nature of the explanatory variables. We therefore include all the firms listed in the Io major European stock markets during the years 200I-20I3 in a single regression model. However, it must be noted that our sample period covers the global financial crisis that began in the USA in mid2007 with the so-called 'sub-prime' mortgage crisis and continued a few months later with the bankruptcy of Lehman Brothers, one of the largest banks in the USA. These events were the beginning of a period of recession in the developed countries, with negative consequences for all economies, including sharp falls in the European stock markets. One could expect that, during such periods of turbulence in the stock markets, investors are more concerned about the level of risk they are assuming rather than other issues such as sustainability. In this context, 


\section{Sustainability Leadership and Firm Valuation}

we believe it essential to analyse to what extent the economic context may influence the initial results obtained for the full sample. For this reason, we also provide empirical evidence for two sub-samples: a first sub-sample from 2001 to 2007 , before the global financial crisis, and a second sub-sample from 2008 to 2013 , covering the economic recession.

We also emphasize that the specific characteristics of each country must be taken into account in this broad analysis of European markets. As we indicated in the introduction, the characteristics of each European market, the CSR policies approved by each government and differences in terms of country's legal origin can influence the market value of sustainability information. Therefore, we include a cross-country analysis.

Here it should be noted that, while some countries such as Germany are reluctant to develop specific regulations, other European governments have been quite active in promoting CSR. This is the case for the UK, Denmark, Norway, Italy, Spain and France, each of which has addressed business sustainability through different policy approaches. Specifically, Albareda et al. (2008) indicate that the UK and Italy rely on a voluntary approach to encourage the adoption of CSR practices through associations of multiple stakeholders for firms, while Norway has adopted legislation to integrate CSR into public policies on sustainable development, the environment and human rights. Galani et al. (2012) note that France also has legislation requiring listed firms to disclose their social and environmental impacts, while Sierra et al. (2013) report on Spanish policies requiring mandatory CSR reporting for all publicly owned firms with more than Iooo employees. More recently, in 2013 the Swedish government introduced a new legal requirement forcing firms to incorporate into their policies aspects such as respect for human rights and a reduction of their impact on climate change (Beare et al., 20I4). In this context, we consider that the country-specific disclosure level is an institutional factor that could explain cross-country variation in the valuation implication of sustainability leadership. More precisely, a higher level of CSR disclosure requirements ensures the value-enhancing effect of sustainability. Therefore, one could expect a more positive association between sustainability leadership and firm value in markets with higher level of CSR transparency.

Finally, differences among legal systems should also be considered to explain cross-country variation in the valuation implication of sustainability. As outlined by La Porta et al. (I999, 2000), the legal system affects economic institutions, their governance structures and, consequently, the profits of these institutions. We therefore believe it necessary to take into account that in common law countries - such as the UK - shareholder protection is stronger and government intervention in the market is rare. By contrast, countries such as Germany, France, Spain, Italy and the Netherlands have a legal system based on civil law, which is characterized by a significant government involvement in corporate structures and more developed laws with regard to employment protection. Consequently, in civil law countries, more than in common law countries, managers are more likely to make decisions in favour of employees or corporate structures, to the detriment of shareholders. Thus, one could expect a less (more) positive association between sustainability leadership and firm value in civil (common) law countries.

\section{Database}

The database employed in this study consists of two types of relevant information: information on sustainability leadership and financial information relevant to the valuation of firms listed on the ro stock markets under study. The two types of information are described below.

\section{Sustainability Leadership Information}

Following the existing literature, in this study we have employed the DJSI Europe Index as a measure of sustainability leadership at the European setting. Applying a best-in-class approach, the DJSI Europe index includes firms from all industries that outperform their peers in numerous sustainability measures based on economic, social and environmental criteria. General aspects such as corporate governance, risk management, branding, mitigation of climate change, supply chain standards and labour practices, as well as industry-specific sustainability criteria, are analysed. Therefore, the firms selected for inclusion in the index are considered sustainability leaders in 
the industry to which they belong. However, the selection criteria evolve each year and firms must continue to make improvements to their long-term sustainability plans in order to remain on the index.

The DJSI Europe index was launched in 200I, coinciding with the publication of the European Union Green Paper (Commission of the European Communities, 200I) in which a common CSR strategy was presented, inviting firms to voluntarily adopt social and environmental measures. Specifically, the purpose of the European Union Green Paper (200I) was to reconcile business objectives with the values and demands of society to promote responsible policies. Over the years, this initiative has been considered as having influenced the development of CSR in Europe (Beare et al., 20I4).

In this context, we analyse I650 firms listed on the stock markets of io European countries - Denmark, Finland, France, Germany, Italy, the Netherlands, Norway, Spain, Sweden and the UK - during the period 200I-20I3. It is a broad sample, not only in terms of the number of firms considered, but also because it covers I3 years of analysis. ${ }^{\mathrm{I}}$ However, it should be noted that our study only considers non-financial firms. We decided to exclude financial firms because they have a specific accounting system that is different from that of other business sectors. ${ }^{2}$

Table I shows the structure of our sample in each of the io European stock markets considered during the period 200I-20I3 and after the exclusion of financial firms. In addition, it shows the number of firms that are part of the DJSI Europe index, as well as the percentage that this group represents of all the firms in the sample. As can be seen in Table I, France, the UK and Germany are the major European markets, with 403, 402 and 363 firms listed in their respective stock markets, the UK being the leader in terms of sustainability with 83 firms that are part of the index over the sample period (which represents $20.65 \%$ of the market), followed by France with 40 and Germany with 37. Meanwhile, the Nordic countries have the highest percentage of leading sustainability firms. More specifically, Denmark has $30.43 \%$ followed by Sweden with $27.45 \%$.

\section{Financial Information}

The financial information required to apply the Ohlson (I995, 200I) valuation model described in the methodology section, particularly the market value and book value of equity at each year end, as well as the annual earnings of each firm, have been obtained from the Thomson Reuters DataStream database.

Table 2 shows the descriptive statistics (mean, maximum, minimum and standard deviation) of these variables, as well as the number of observations in the sample. We use a specification of the Ohlson (I995, 200I) model based on share prices, as recommended by Barth and Clinch (2009), to mitigate any scale effects present in the sample. For this reason, the information in Table 2 is provided in per share rates. As we can see, the average share price of the firms in the sample is 17.95 with a standard deviation of 29.57 , the mean book value per share is 12.80 with a standard deviation of 30.59 and the average earnings per share is I.2I with a standard deviation of 2.6. In addition, it should be noted that observations with a negative book value were eliminated from the sample, in accordance with the recommendations of Lourenço et al. (20I2, 20I4). In addition, to ensure that the regression results were not influenced by outliers in the sample, we ranked market value in ascending order and the firms in the top and bottom $2.5 \%$ in each country were eliminated. ${ }^{3}$ As a result, we have a total of I8 694 observations in the sample.

\section{Empirical Results}

\section{Empirical Results for Europe}

We initially present the results obtained by applying the Ohlson (I995, 200I) model to the valuation of the firms listed in Io major European markets as a whole. The results presented in Table 3 are for the entire sample from $200 \mathrm{I}$ to 2013 , as well as for the two sub-samples corresponding to the years 200I-2007 and 2008-2013 respectively,

\footnotetext{
${ }^{\mathrm{I}}$ The remainder of the European markets were excluded from the study because the number of listed firms included in the DJSI Europe index was limited, even non-existent in some years of the sample.

${ }^{2}$ Following existing studies such as those of Hassel et al. (2005) and Moneva and Cuellar (2009), among others.

${ }^{3}$ This procedure is in accordance with prior literature, having been studied and discussed by Curto et al. (2OII).
} 
Sustainability Leadership and Firm Valuation

\begin{tabular}{lccc}
\hline Market & Number of listed firms & DJSI Europe membership \\
\cline { 3 - 4 } & & Number & \% \\
\hline Denmark & 23 & 7 & 30.43 \\
Finland & 103 & 16 & 15.53 \\
France & 403 & 40 & 9.93 \\
Cermany & 363 & 37 & 10.19 \\
Italy & 112 & 15 & 13.39 \\
Netherlands & 83 & 21 & 25.30 \\
Norway & 32 & 8 & 25.00 \\
Spain & 78 & 20 & 25.64 \\
Sweden & 51 & 14 & 27.45 \\
UK & 402 & 83 & 20.65 \\
\hline
\end{tabular}

Table 1. The structure of the sample in each of the 10 European stock markets considered during the period of 2001-2013, after the exclusion of the financial sector and the extraction of outliers, as well as the number and percentage of these firms that are included in the DJSI Europe

in order to provide evidence in two different economic states: before the global financial crisis and during the

\begin{tabular}{lccc}
\hline & Market value & Book value & Earnings \\
\hline Mean & 17.957 & 12.800 & 1.211 \\
Maximum & 426.649 & 886.792 & 47.680 \\
Minimum & 0.013 & 0.000 & 0.000 \\
Standard deviation & 29.573 & 30.598 & 2.674 \\
Number of observations & 18694 & & \\
\hline
\end{tabular}

Table 2. The descriptive statistics (mean, maximum, minimum and standard deviation) of the market value, book value and earnings per share variables of the 10 European markets as a whole during the 2001-2013 period. Finally, the number of observations is provided

\begin{tabular}{|c|c|c|c|}
\hline Intercept & $6.990 \% * * \%(0.00)$ & $4.599^{\text {米柴 }}(0.00)$ & $3.583^{* \ldots+k}(0.00)$ \\
\hline Earnings & $1.897^{* * * * *}(0.00)$ & $1.958^{* \ldots * * 0}(0.00)$ & $0.870^{* * * * *}(0.00)$ \\
\hline DJSI Europe GRI & 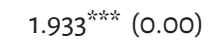 & $1.678^{* *}(0.03)$ & $2.034^{* \ldots+*}(0.01)$ \\
\hline Adjusted $R^{2}$ & 0.835 & 0.869 & 0.903 \\
\hline Hausman test & $409.09^{* * * * *}$ & $411.97^{* \% * *}$ & $474.87^{* \cdots * *}$ \\
\hline Fixed or random effects & fixed & fixed & fixed \\
\hline Number of observations & 18746 & 9389 & 9357 \\
\hline
\end{tabular}

Table 3. Empirical results for the 10 European markets. This table shows the results of the Ohlson (1995, 2001) valuation model in Europe during the 2001-2013 period, and over the sub-periods of 2001-2007 and 2008-2013. The explanatory variables are the book value and earning per share as well as a dummy variable that takes the value 1 if a company is included in the DJSI Europe index in the respective year and o otherwise. Due to the sample panel data, and based on the Hausman test, fixed effect regressions are conducted. The values of the adjusted $R^{2}$ and $F$ statistics as well as the number of observations are presented

*w*

**'and

"represent significance levels of 1\%, 5\% and 10\% respectively 
economic recession. It is important to outline that in each case we have employed an OLS panel data method and, based on the Hausman test, fixed or random effect regressions were conducted. Moreover, the overall significances of the model regressions are provided by showing the adjusted $R^{2}$ as well as the $F$ tests.

As expected, we see in Table 3 that the coefficients for book value per share and earnings per share are positively and significantly associated with share price. In addition, the coefficient of belonging to the DJSI Europe index is positive and statistically significant at a I\% level. It indicates that the European markets as a whole value the socially responsible firms included in the European sustainability index for the period 200I-20I3. These overall results are similar to those obtained by Kaspereit and Lopatta (2016) for the 600 largest European firms and indicate that having CSR policies leading to sustainability leadership is important for European investors, thus corroborating the value-creating theory. Our results also give support to the view of McWilliams et al. (2016), who outline that CSR practices have become an important element of differentiation in business strategy, as well as to that of Escrig-Olmedo et al. (20I7), who indicate that investors have a positive attitude to firms that strongly contribute to sustainable development.

These findings are therefore especially relevant for the managers of these firms, because they reveal that leadership in sustainability practices results in sustainable competitive advantage that is valued by the investment community. In this sense, we must note that investors are key stakeholders for listed firms and can exert considerable influence over the sustainability strategy of the firms in which they invest. As a result, the credibility of this type of information and the confidence investors have in it are associated with an increase in the value of shares.

However, we must take into account that the Ohlson (I995, 200I) valuation model is based on a positive and significant correlation between the predicted market value of equity and its explanatory variables. This correlation could be different in periods of recession, such as the last one that began in the USA in mid-2007 and spread across the world in the following months, especially affecting European countries. For that reason, we divide our sample period into two sub-samples - from 2001 to 2007 and from 2008 to 2013 - in order to provide evidence in two different economic states. As we can see in Table 3, investors positively value leading sustainability firms in the two sub-periods. In addition, we observe that the results are more statistically relevant in the second sub-sample. These results therefore indicate that efforts in sustainability are especially valued in times of crisis.

\section{Empirical Results for each European Market}

As indicated in the methodology section, it is essential to take into account the specific characteristics of each country in this broad analysis of the European context. For this reason, we provide evidence on each market individually. The results of the regression model applied to each European market in the period from $200 \mathrm{I}$ to 2013 are presented in Table 4 . We can see that the coefficients associated with the book value and earnings per share are positive and significant for almost all markets. However, we can also see that the coefficient associated with the DJSI Europe variable is only positive and significant for the German and Swedish markets, with a significance level of I\% and I०\% respectively. The rest of the markets do not have statistically significant values.

These results show that there are large differences between markets and contribute to the debate about the most appropriate public policy on CSR. As we have stated above, the governments of the UK, Norway, France, Italy, Spain and Denmark have developed public CSR policies. However, the information on sustainability leadership is not significant in these markets. In contrast, Sweden, which adopted a national CSR reporting law in 20I3, and Germany, which is still resisting this commitment, are the markets where information on sustainability leadership is positively and significantly valued.

However, before drawing any general conclusions, in Tables 5 and 6 we present the results of the regression model applied to each European market in the 200I-2007 and 2008-20I3 sub-samples respectively, in order to provide evidence in two different economic states. In these cases, we see that the German market is the only one where sustainability leadership is valued in the two sub-samples, since the significance previously observed in the Swedish market is limited to the second sub-sample. In contrast, we also see that sustainability leadership information is positively and significantly valued in the Norwegian market in the first sub-sample and in the Spanish market in the second sub-sample. In the other markets, the coefficient for the DJSI Europe variable is not statistically significant. 


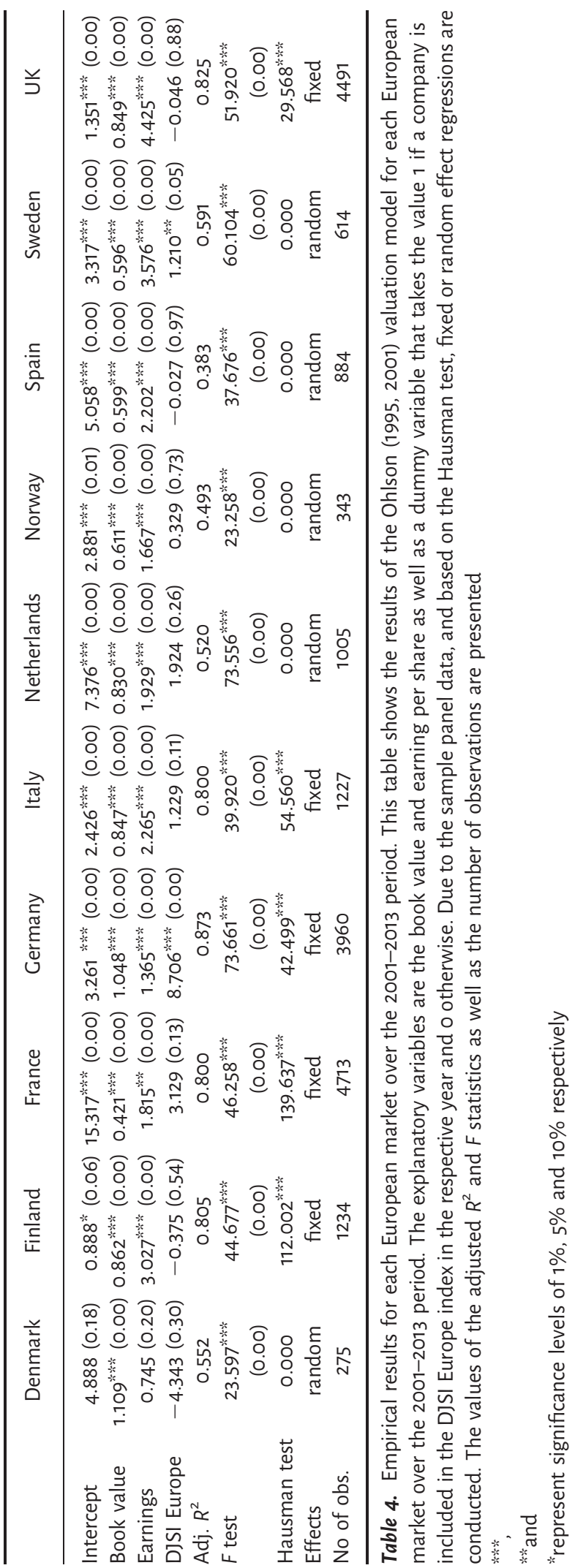




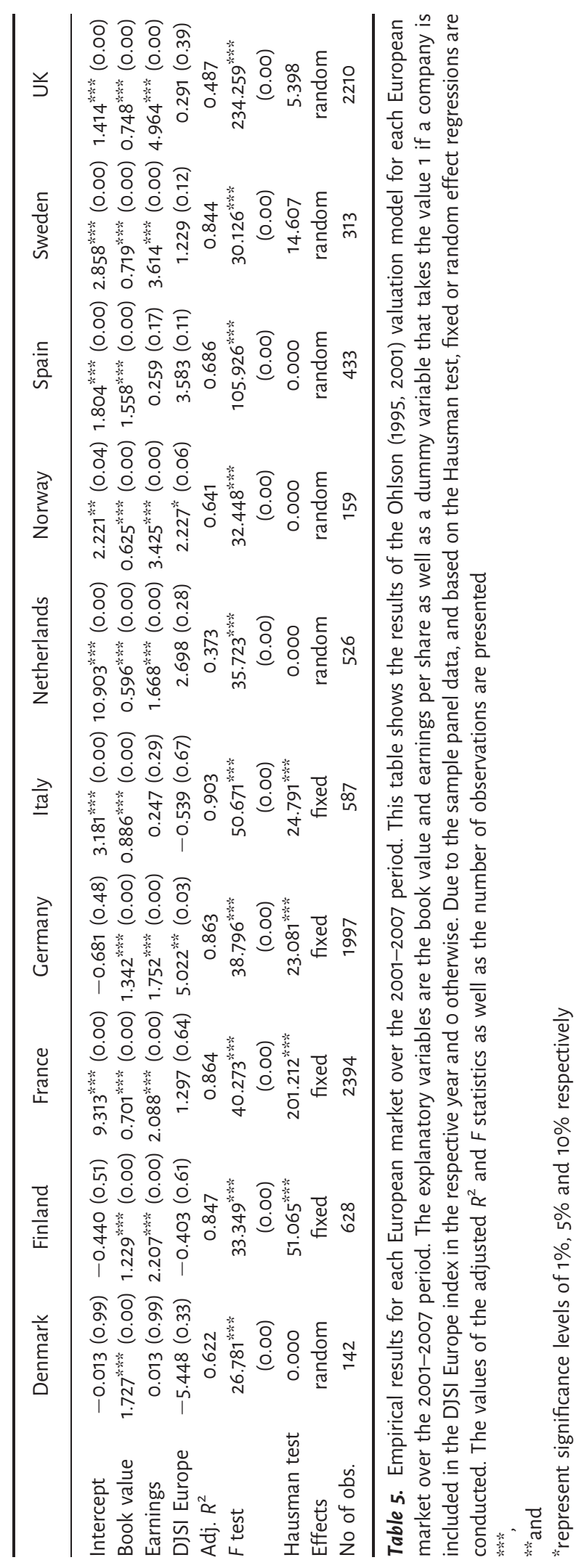




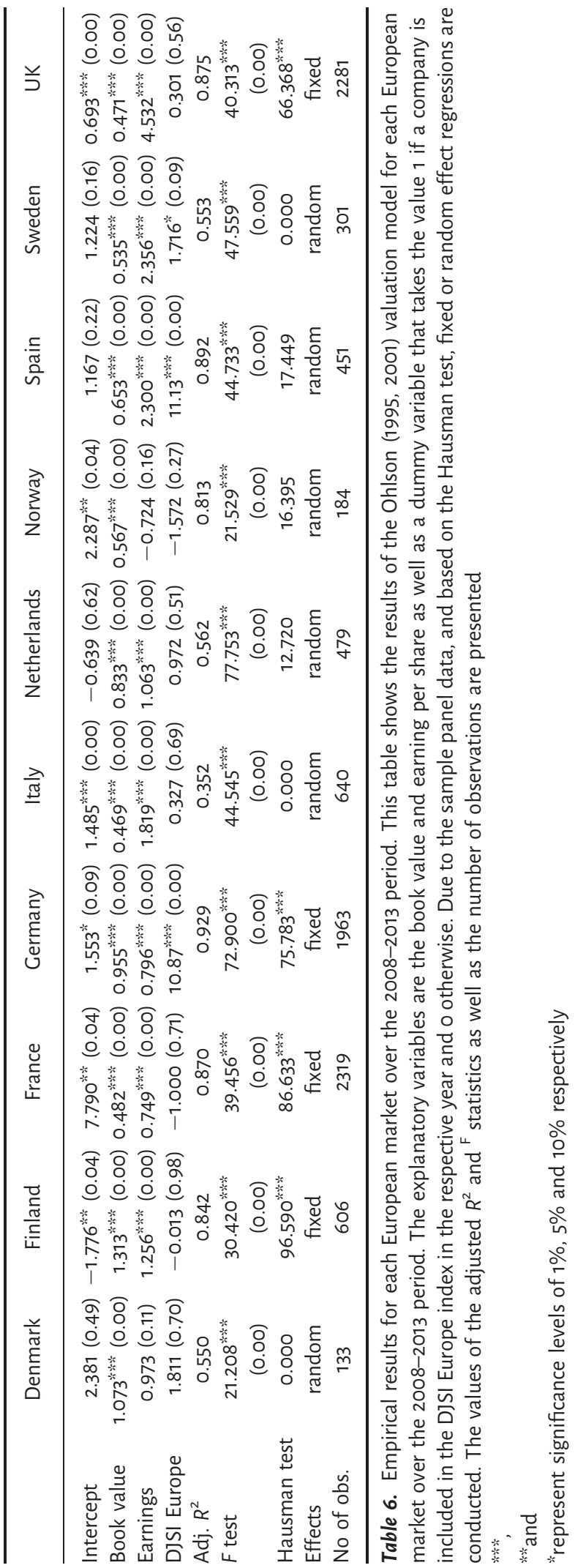


These findings indicate that sustainability leadership is significantly valued in a reduced number of European markets, although this valuation seems to have a positive sign, as predicted by the value-creating theory. Therefore, belonging to the DJSI Europe index is understood by investors as a strategic advantage that positively affects value. By contrast, there is no evidence in favour of the value-destroying theory even in the years of economic crisis.

The case of the UK is especially striking. As Aguilera et al. (2007) outline, CSR information is expected to be more valued in this country because of its commitment to CSR and its legal system, characterized by laws that provide stronger protection to shareholders. However, the results obtained in this study do not support this argument. In contrast, our results are in line with the argument provided by Carnevale and Mazzuca (20I4), who indicated that in countries such as the UK the sign of the relationship between corporate sustainability performance and firm's market value is less positively significant than in other countries. This is because the firm's market value in the UK relies on different short-term factors such as profitability. Moreover, our results corroborate those previously documented by Ziegler (20I2) when analysing the relationship between the financial performance and sustainability performance of European firms. Non-significant results were found for the UK, while the results for German firms were positive and significant.

In this regard, it should be noted that many large German firms are internationally recognized for their CSR practices and are very advanced in environmental performance, as well as in social dialogue and stakeholder participation (Beier, 20I2). However, these are generally firms belonging to the industrial sector. As Kaspereit and Lopatta (20I6) argue, if a firm's sustainability leadership over other firms in its sector generates shareholder value, it being more sustainable than its competitors will depend on the extent to which there are competitive advantages from this. Therefore, expected earnings are conditional on the state of implementation of corporate sustainability in the sector.

Finally, the differences among countries and economic states that are detected in this study reveal that there should be joint efforts by national governments to develop robust polices that contribute to reducing them, as well as encouraging sustainability. European Union policymakers also have a relevant role in this field in order to continue the spread and harmonization of CSR issues across Europe. Ultimately, as Miralles-Quiros et al. (20I7) outline, international financial organizations and listed firms should also join their efforts to commit to sustainability in order to gain quality, visibility and credibility for the investment community. As a consequence, this would also contribute to fostering socially responsible investment.

\section{Conclusions}

Investment in socially responsible firms has grown considerably around the world and especially in Europe in recent decades. In this context, and given the influence of the economic policies established by the European Commission over these years, as well as the policies and legislation of each European country, many firms quoted on the European stock markets are inclined to adopt CSR practices.

Meanwhile, analysts and investors usually employ sustainability indices as an integrated measure of firm sustainability performance and leadership. Following a best-in-class approach, sustainability indices include companies across all industries that outperform their peers in an in-depth analysis of economic, environmental and social criteria. Therefore, firms selected to be included in these indices are considered to be industry sustainability leaders.

Following some previous studies that have found a significant relation between the market value of equity and non-financial information such as environmental performance or social and environmental reporting, we extend these conclusions to the issue of sustainability leadership. In this context, the aim of this study has been to analyse whether investors in the stock markets of Denmark, Finland, France, Germany, Italy, the Netherlands, Norway, Spain, Sweden and the UK value the information provided by the DJSI Europe index during the period 200I2013, taking into account the specific characteristics of each market and the economic cycle. This analysis was carried out using the Ohlson (I995, 200I) valuation model. Hence this contributes to the literature by bringing additional evidence on the value relevance of non-financial information. 


\section{Sustainability Leadership and Firm Valuation}

Our overall results are consistent with the value-creating theory, as opposed to the value-destroying theory, regarding the role of sustainability leadership in firm valuation even in the years of economic recession. These findings support the belief that conducting business in accordance with norms that integrates economic, social and environmental principles is a differentiation business strategy that contributes to shareholder value creation. We therefore consider that sustainability leadership should be a mandate for the strategic managers of listed firms.

However, our results also reveal that the positive impact of sustainability leadership on firm value is primarily driven by German and Swedish listed firms, while markets with stronger shareholder protection and higher requirements for CSR transparency do not provide significant results. In this sense, we have to highlight that there should be joint efforts by national governments and European Union policymakers to increase the commitment to sustainability and create common and robust polices that promote the visibility and credibility of CSR issues and contribute to reducing differences across Europe.

Future research should focus on analysing differences across industries in the value relevance of sustainability leadership. It would be particularly interesting to examine whether the value relevance of sustainability leadership in the German market is exclusively due to industrial firms. In addition, it would be interesting to provide evidence for financial institutions, which, due to their singular accounting characteristics, have not been considered in this research.

\section{Acknowledgements}

The authors thank the editor and two anonymous referees for valuable suggestions, which helped to considerably improve the quality of this study. This paper has been financially supported by the Junta de Extremadura under the V Action Plan for Research and Development 20I4/I7 through the GIMAF research group (reference GRI5027).

\section{References}

Aguilera RV, Rupp DE, Williams CA, Ganapathi J. 2007. Putting the S back in corporate social responsibility: a multilevel theory of social change in organizations. Academy of Management Review 32(3): 836-863.

Al-Najjar B, Anfimiadou A. 20I2. Environmental policies and firm value. Business Strategy and the Environment 2I(I): 49-59.

Albareda L, Lozano J, Tencati A, Midttun A, Perrini F. 2008. The changing role of governments in corporate social responsibility: drivers and responses. Business Ethics I7(4): 347-363.

Ball A, Broadbent J, Jarvis T. 2006. Waste management, the challenges of the PFI and sustainability reporting. Business Strategy and the Environment 15(4): 258-274.

Barnea A, Rubin A. 20I0. Corporate social responsibility as a conflict between shareholders. Journal of Business Ethics 97: 7I-86.

Barth ME, Clinch G. 2009. Scale effects in capital markets-based accounting research. Journal of Business Finance and Accounting 36(3/4): $253-288$.

Beare D, Buslovich R, Searcy C. 20I4. Linkages between corporate sustainability reporting and public policy. Corporate Social Responsibility and Environmental Management 2I(6): 336-350.

Beier J. 20I2. CSR 'made in Germany': are voluntary standards enough? Business for Social Responsibility Report. https://www.bsr.org/ourinsights/blog-view/csr-made-in-germany-are-voluntary-standards-enough [3I March 20I7].

Berthelot S, Coulmont M, Serret V. 20I2. Do investors value sustainability reports? A Canadian study. Corporate Social Responsibility and Environmental Management I9(6): 355-363.

Bowerman S, Sharman U. 20I6. The effect of corporate social responsibility disclosures on share prices in Japan and the UK. Corporate Ownership and Control I3(2): 202-216.

Cardamone P, Carnevale C, Giunta F. 20I2. The value relevance of social reporting: evidence from listed Italian companies. Journal of Applied Accounting Research 13(3): 255-269.

Carnevale C, Mazzuca M. 20I4. Sustainability reporting and varieties of capitalism. Sustainable Development 22(6): $36 \mathrm{I}-376$.

Carnevale C, Mazzuca M, Venturini S. 20I2. Corporate social reporting in European banks: the effects on a firm's market value. Corporate Social Responsibility and Environmental Management 19(3): 159-I77.

Chapple L, Clarkson P, Gold D. 20I3. The cost of carbon: capital market effects of the proposed emission trading scheme (ETS). Abacus 49(I): I-33.

Charlo MJ, Moya I, Muñoz AM. 20I5. Sustainable development and corporate financial performance: a study based on the FTSE4Good IBEX Index. Business Strategy and the Environment 24(4): 277-288. 
Cheung A. 20II. Do stock investors value corporate sustainability? Evidence from an event study. Journal of Business Ethics 99: I45-165.

Commission of the European Communities. 200I. Green Paper: Promoting a European Framework for Corporate Social Responsibility, COM (200I) 366 final. Brussels.

Cormier D, Magnan M. 2007. The revisited contribution of environmental reporting to investors' valuation of a firm's earnings: an international perspective. Ecological Economics 62(3/4): 618-626.

Curto J, Morais A, Lourenço I, Pinto J. 20II. The heteroscedasticity-consistent covariance estimator in accounting. Review of Quantitative Finance and Accounting 37: 427-428.

De Klerk M, De Villiers C, Van Staden C. 20I5. The influence of corporate social responsibility disclosure on share prices. Evidence from the United Kingdom. Pacific Accounting Review 27(2): 208-228.

De Silva Lokuwaduge CS, Heenetigala K. 20I7. Integrating environmental, social and governance (ESG) disclosure for a sustainable development: an Australian study. Business Strategy and the Environment in press. https://doi.org/10.1002/bse.I927

Eisenbach S, Schiereck D, Trillig J, von Flotow P. 20I4. Sustainable project finance, the adoption of the equator principles and shareholder value effects. Business Strategy and the Environment 23(6): 375-394.

Escrig-Olmedo E, Muñoz-Torres MJ, Fernández-Izquierdo MA. 20I7. Measuring corporate environmental performance: a methodology for sustainable development. Business Strategy and the Environment 26(2): I42-I62.

European Union. 200I. Green Paper. Promoting a European framework for corporate social responsibility.

Fifka MS. 20I3. Corporate responsibility reporting and its determinants in comparative perspective - a review of the empirical literature and a meta-analysis. Business Strategy and the Environment 22(I): I-35.

Galani D, Gravas E, Stavropoulos A. 20I2. Company characteristics and environmental policy. Business Strategy and the Environment 2I(4): 236-247.

Godfrey P, Merrill C, Hansen J. 2009. The relationship between corporate social responsibility and shareholder value: an empirical test of the risk management hypothesis. Strategic Management Journal 30(4): 425-445.

Goettsche M, Steindl T, Gietl S. 20I6. Do customers affect the value relevance of sustainability reporting? Empirical evidence on stakeholder interdependence. Business Strategy and the Environment 25(3): I49-164.

Hassel L, Nilsson H, Nyquist S. 2005. The value relevance of environmental performance. European Accounting Review I4(I): 4I-6I.

Hussainey K, Salama A. 20I0. The importance of corporate environmental reputation to investors. Journal of Applied Accounting Research II(3): 229-24I.

Jackson G, Apostolakou A. 20Io. Corporate social responsibility in Western Europe: an institutional mirror or substitute. Journal of Business Ethics 94(3): 37I-394.

Kaspereit T, Lopatta K. 20I6. The value relevance of SAM's corporate sustainability ranking and GRI sustainability reporting in the European stock markets. Business Ethics 25(I): I-24.

Kolk A. 2008. Sustainability, accountability and corporate governance: exploring multinationals' reporting practices. Business Strategy and the Environment I7(I): I-I5.

La Porta R, Lopez-de-Silanes F, Shleifer A. 1999. Corporate ownership around the world. Journal of Finance 54: 47I-518.

La Porta R, Lopez-de-Silanes F, Shleifer A, Vishny RW. 2000. Investor protection and corporate governance. Journal of Financial Economics 58 : $3-27$.

Lee KH, Cin BC, Lee EY. 20I6. Environmental responsibility and firm performance: the application of an environmental, social and governance model. Business Strategy and the Environment 25(I): 40-53.

Lo SF, Sheu HJ. 2007. Is corporate sustainability a value-increasing strategy for business? Corporate Governance I5(2): 345-358.

Lourenço I, Callen J, Branco M, Curto J. 20I4. The value relevance of reputation for sustainability leadership. Journal of Business Ethics II9: I7-28.

Lourenço I, Callen J, Branco M, Curto J, Eugenio T. 20I2. How does the market value corporate sustainability performance? Journal of Business Ethics 108: 4I7-428.

Maignan I. 200I. Consumers' perceptions of corporate social responsibilities: a cross-cultural comparison. Journal of Business Ethics 30(I): 57-72.

Marom Y. 2006. Toward a unified theory of the CSP-CFP link. Journal of Business Ethics 67(2): I9I-200.

McWilliams A, Parhankangas A, Coupet J, Welch E. 20I6. Strategic decision making for the triple bottom line. Business Strategy and the Environment 25(3): I93-204.

Mervelskemper L, Streit D. 20I7. Enhancing market valuation of ESG performance: is integrated reporting keeping its promise? Business Strategy and the Environment in press. https://doi.org/Io.1002/bse.I935

Miralles-Quiros MM, Miralles-Quiros JL, Arraiano IG. 20I7. Are firms that contribute to sustainable development valued by investors? Corporate Social Responsibility and Environmental Management 24(I): 7I-84.

Miras-Rodríguez MM, Carrasco-Gallego A, Escobar-Perez B. 20I5. Are socially responsible behaviors paid off equally? A cross-cultural analysis. Corporate Social Responsibility and Environmental Management 22(4): 237-256.

Moneva JM, Cuellar B. 2009. The value relevance of financial and non-financial environmental reporting. Environmental and Resource Economics 44(3): $44 \mathrm{I}-456$.

Oberndorfer U, Schmidt P, Wagner M, Ziegler A. 20I3. Does the stock market value the inclusion in a sustainability stock index? An event study analysis for German firms. Journal of Environmental Economics and Management 66: 497-509.

Ohlson JA. I995. Earnings, book values and dividends in equity valuation. Contemporary Accounting Research II(2): 66I-686.

Ohlson JA. 200I. Earnings, book values and dividends in equity valuation: an empirical perspective. Contemporary Accounting Research I8(I): I07-I20.

Pérez-López D, Moreno-Romero A, Barkemeyer F. 20I5. Exploring the relationship between sustainability reporting and sustainability management practices. Business Strategy and the Environment 24(8): 720-734. 


\section{Sustainability Leadership and Firm Valuation}

Robinson M, Kleffner A, Bertels S. 20II. Signaling sustainability leadership: empirical evidence of the value of DJSI membership. Journal of Business Ethics Ior: 493-505.

Schadewitz H, Niskala M. 20I0. Communication via responsibility reporting and its effect on firm value in Finland. Corporate Social Responsibility and Environmental Management I7(2): 96-106.

Scholtens B. 2009. Corporate social responsibility in the international banking industry. Journal of Business Ethics 86: I59-I75.

Searcy C, Elkhawas MJ. 20I2. Corporate sustainability ratings: an investigation into how corporations use the Dow Jones Sustainability Index. Journal of Cleaner Production 35: 79-92.

Sierra L, Zorio A, Garcia-Benau M. 20I3. Sustainable development and assurance of corporate social responsibility reports published by Ibex-35 companies. Corporate Social Responsibility and Environmental Management 20(6): 359-370.

Xu XD, Zeng SX, Zou HL, Shi JJ. 20I6. The impact of corporate environmental violation on shareholders' wealth: a perspective taken from media coverage. Business Strategy and the Environment 25(2): 73-9I.

Yadav PL, Han SH, Rho JJ. 20I6. Impact of environmental performance on firm value for sustainable investment: evidence from large US firms. Business Strategy and the Environment 25(6): 402-420.

$\mathrm{Yu}$ M, Zhao R. 2015. Sustainability and firm valuation: an international investigation. International Journal of Accounting and Information Management 23(3): 289-307.

Ziegler A. 20I2. Is it beneficial to be included in a sustainability stock index? A panel data study for European firms. Environmental and Resource Economics 52: 30I-325. 